\title{
Terrorism or Clamor for Resource Control: An Analysis of Nigeria's Niger Delta Militants
}

\section{by John Oghenero Tobor}

\section{(cc) $\mathrm{BY}$}

This work is licensed under a Creative Commons Attribution 3.0 License.

\begin{abstract}
The purpose of this study is to find out whether the activities of the Niger Delta militants can be classified as acts of terrorism or a clamor for resource control. The engagement tactics of kidnappings, attacks on oil infrastructural facilities and the placement of bombs and other explosive devices in public places suggest to some observers that the Niger Delta militants should be considered terrorists. Using content analysis of relevant secondary data, with insights from the experiences and perceptions of the study participants, this paper examines the engagement tactics of the Niger Delta militants. The findings may be useful in contributing to the development of policies that address the Niger Delta crisis. Similarly, key stakeholders equipped with such vital information derived from the result findings may understand, appreciate, identify, and develop appropriate strategies and guidelines that can be used to address the reasons behind the Niger Delta conflicts. All of these may lead to improvement in the lives of the residents that inhabit the land. Findings of this study may also enable the multinational oil corporations to re-evaluate their strategies and mode of operations and come up with better ways to operate in a peaceful environment, and thus contribute steadfastly and uninterruptedly to the Nigerian economy. All these may invariably lead to positive social change. Much of the empirical evidence to be presented derives from my own research.
\end{abstract}

Keywords: Crisis; conflicts; ex-militant; Niger Delta; Nigeria; resource control; terrorism.

\section{Introduction}

everal researchers defined the Niger Delta region to include nine states namely Delta, Rivers, Bayelsa, Edo, Akwa Ibom, Abia, Cross River, Ondo, and Imo State (Badmus, 2010; Idowu, 2012; Odoemene, 2011; Okpo \& Eze, 2012; Olankunle, 2010). Obi (2010) described the Niger Delta region as a vast coastal plain situated at the southernmost part of Nigeria where the River Niger drains into the Atlantic Ocean. Paki and Ebienfa (2011) referred to the region as one of the richest deltas in the world. The region covers about 70, 000 square kilometers of watery maze of intricate marshland, lagoons, tributaries, extensive fresh water swamps, rich fisheries deposits, and creeks (Obi, 2010; Odoemene, 2011; Okpara, 2012; Omotola, 2012). The region is made up of ecological zones that range from sandy coastal ridge barrier to lowland rainforest teeming with towering mangrove plants, marine life, bird, giant ferns, and the forests (Amadi \& Abdullah, 2012; Obi, 2010). It is considered to be the largest wetland in Africa and one of the largest in the world (Ifedi \& Anyu, 2011; Nte, Eke, \& Anele, 2010; Obi, 2010; Ogbodo, 2010; Omotola, 2010; Paki \& Ebienfa, 2011). Obi (2010) emphasized that the region provides a habitat for a vast biodiversity from its rich resource base. According to Omotola (2010), the region has natural gas reserves of about 163 trillion cubic feet and harbors crude oil reserves of 33 billion barrels. The region has a population of about 28.9 


\section{Journal of Terrorism Research}

million people (Ogege, 2011; Okpara, 2012). Badmus (2010) described the Niger Delta region as a zone of demographic minorities comprised of different ethnic tribes that include the Urhobos, the Ijaws, Ibibios, Kalabari, Itshekiris, Efiks, Isoko, Nembe, Ndom, Andoni, and Ikwerre (Badmus, 2010; Okpo \& Eze, 2012). Ekpeyong and Dienye (2010) argued that the region became very important in Nigeria's economic, social, and political equations when oil was first discovered in commercial quantities in Olobiri in 1953. A majority of the researchers on Niger Delta agreed that oil is the predominant source of revenue for the Nigerian economy and accounts for over $90 \%$ of export earnings and about $80 \%$ of federal revenues (Agbonifo, 2009; Badmus, 2010; Etemike, 2012; Obi, 2010; Okpara, 2012; Ogege, 2011). Agbonifo explained that the Niger Delta has about 11 multinational oil corporations that operate about 159 oil fields and 1,481 oil wells. Anele and Omoro (2012) asserted that oil revenue derived from the Niger Delta region accounts for more than $90 \%$ of Nigeria's wealth. In spite of the Niger Delta's dominant contribution to the national economy, the general state of the region reflects extreme poverty, underemployment, pollution, neglect, underdevelopment, and lack of proper and adequate infrastructure (Amadi \& Abdullah, 2012; Obi, 2010).

Oil-related conflicts in the Niger Delta, Nigeria date back to the 1970s when Oil Producing Communities (OPCs) began agitations against Multinational oil corporations (MOC) over concerns about oil-induced environmental devastation, MOC reluctance to support community development, and inadequate compensation for damages to properties caused by the operational activities of the MOC. The failure of the Nigerian Government to adequately address the myriad grievances instigated several developments, resulting in the formation of militia groups that mobilized a violent struggle against the Nigerian State. The Niger Delta militants' use of violence as a strategy of engagement and method to communicate political objectives has raised concerns as to whether their activities fall under the heading of terrorism or quest for resource control. The meaning and applicability of such a term is highly debated because it elicits different meanings to different people, and at times different things to the same person in different contexts. While it can be viewed through the prisms of crime, politics, communication, religion and warfare, there have been many attempts to create a definition of terrorism that can be applied to various contexts.

Classic definitions of terrorism often include the use of violence to compel a government or society to act in a certain way. While the aforementioned classification could easily apply to the tactical behavior of the Niger Delta militants, the question is then whether it can be viewed as an act of terrorism or as an avenue to draw attention to their cries and clamor for resource control. The main objective of this article is to discuss the targeting behavior of the Niger Delta militants and determine whether it falls within the context of terrorism or quest for resource control. The struggles of the Niger Delta people can be appreciated through the lens of the political economy approach. Political economy falls within the broader critical theory perspective. Ekpeyong and Dienye (2010) utilized the political economy approach to effectively amplify the problems of the Niger Delta region. The approach posits that economic relations defines or reinforces the struggle for power, which ultimately results in conflicts. However, the continued denial of any effective political identity provided the motivation and impetus that gave rise to the crisis in the Niger Delta region. The problems of the Niger Delta can be associated with the aspirations of the indigenous people for effective representation in government that would translate to political, social, and economic emancipation.

\section{Methodology}

The study adopted a qualitative research method. The study participants included 20 ex-militants from Urhobo origin. The Urhobos make up a sizeable and significant portion of the total population of the Niger 


\section{Journal of Terrorism Research}

Delta region. Ekeh (2008) emphasized that the Urhobos are the most populated group in the Western Niger Delta region and fifth largest ethnic group in Nigeria. They live amongst other ethnic groups in the Niger Delta region and share similar social background. Participants in this study were not randomly selected, but rather they were chosen based on certain distinctive features. The 20 ex-militants chosen were all males and they cut across status, age, religious, and various professional backgrounds. For instance, some of the respondents include farmers, fishermen, activists, artisans, and traders. The number 20 was determined to be adequate for the reason that the fewer participants in this type of study, the more depth I was able to get from the interviews.

In order to address the issue of confidentiality, the participants are identified and designated with a letter $\mathrm{P}$ (for participant), and a corresponding number (for instance, P1, P2, P3, etc.) assigned to them in the order in which they were interviewed. Their ages ranged from 20 to 45 years. Ethical consideration was taken into account. For instance, the rights and responsibilities of the participants were explained to them in great detail as indicated by the Institutional Review Board guidelines and regulations. Participants were also advised that their participation is voluntary and that they could opt out of the study without giving any reason or cause. All the study participants were given an opportunity to review and sign the informed consent form. Twenty face-to-face interviews with the use of 23 open-ended questions were conducted in a 4-week period. The interviews were recorded on a Sony PCM-M10/B portable digital field audio recorder and subsequently stored on a laptop computer. The interviews were then transcribed verbatim into a Microsoft word document. Prior permission was obtained before each recording. In order to ensure evidence of trustworthiness in the study, member checking was employed during and after the interview. The data collected were content-analyzed.

Triangulation is a validity strategy that was used to ensure credibility of this study. The use of an ethnographic research design reduced threats to validity and by employing multiple sources to collect data led to triangulation over an extended period of time. In order to address the issue of confirmability, reflexive bracketing was used to give meaning to the daily lived experiences of the study participants. Transcripts were returned to participants to verify accuracy and corroborate the data analyzed. This provided an opportunity for the participants to review and clarify any ambiguities, the meanings of their statements, views, and comments expressed during the interview process. The conceptual framework for Tobor (2014) was based on Oakley's (1989) concepts of community participation, while Benet's $(2006,2012,2013)$ polarities of democracy provided the theoretical framework for the study.

\section{Competing perspectives of terrorism}

When one tries to define terrorism, one is astonished by the multiplicity of definitions already proposed by philosophers. They are so different that no consensus seems likely to be reached. Failure to produce a standard definition is because Nation-states, sub state organizations, scholars and non-state actors have often rejected definitions that undermine their modus operandi in any insurrectionary situation (Chase, 2013). The appellation of terrorism is appropriately and or inappropriately used by the constructor in any given circumstance to pursue set goals (Bongar, Brown, Beutler, Breckenridge, \& Zimbardo, 2007). It is against this background that the formulation of an adequate definition seems impossible. However, what is generally agreed on is that the word terrorism has a very strong negative connotation. Some definitions of terrorism are in fact justifications or condemnations of certain forms of violence rather than adequate and exhaustive descriptions of the phenomenon. Furthermore, it is indeed commonly agreed that terrorism pursues its aim 


\section{Journal of Terrorism Research}

by creating a situation of fear and more precisely of terror in a group or in a population. This is why terrorism is widely seen as an extreme form of violence because it has a psychological impact much deeper than its physical consequences.

Nacos (2012) in tracing the origin and definition of the term terrorism gave an account of the 18th century French Revolution. Nacos described violent actions as tools of oppression engaged by those in state power to oppress, cow, minimize, and suppress oppositions during the reign of terror. However, by the middle of the 19th century the definition of terrorism seemed to have been extended to indicate the use of force by the seemingly oppressed class against those in power in order to challenge, stop or overturn the reign of terror (Nacos, 2012). The latter definition reflects the feud often between the reign of terror and fight-back as a defense mechanism of freedom-fighters. The semantics of constructing the aggressor as a freedom-fighter, militia, terrorists, and or government, becomes a function of propaganda and dialectic bias. The deployment of the instrumentality of violence could be used in furtherance of political, economic or social objectives (Chase, 2013; Nacos, 2012). According to Nacos (2010), the ambiguity about the definition of terrorism deserves attention because the choice of language may determine or influence how politically motivated violence is perceived inside and outside a targeted society. Rubenstein (1988) posited that terrorism portrays violent action of individuals or small groups, with implicit connotation of illegitimacy. Cooper (2001) defines terrorism as the intentional generation of massive fear by human beings for the purpose of securing or maintaining control over other human beings. This definition might not satisfy many who try to find a substantial one to sum all the phenomena.

\section{Background to the study}

Though the link between oil, deprivation and conflict in the Niger Delta has been extensively discussed in the literature, it is important to underscore some of the issues related to the Niger Delta context. The rising violence in Niger Delta, Nigeria is a function of the continuation of the struggle for resource control by any means necessary. It is therefore not a surprise to associate criminal tendencies that usually accompany such struggles. The literature reviewed (Agbonifo, 2009; Badmus, 2010; Bassey, 2012; Idowu, 2012; Ifedi \& Anyu, 2011; Ogege, 2011; Okpo \& Eze, 2012; Oluduro \& Oluduro, 2012; Oluwaniyi, 2011;Tobor, 2016) indicated that while oil production is easily Nigeria's most crucial economic life-line and has been the major contributor to the nation's overall economic development over the decades, the oil bearing Niger Delta communities have basically remained persistently deprived of the benefits of oil resources. Instead of improving the quality of life of the inhabitants of the region, the discovery and exploitation of oil has led to worse living standards, lost income for the inhabitants as their main source of livelihood from fishing, carving, and dwindling agricultural sector was not replaced with employment in another industry (Agbonifo, 2009).

Researchers such as Akpan and Ering (2010), Bassey (2012), and Paki and Ebienfa (2011) argued that the root cause of the Niger Delta conflicts are legitimate; and they attribute political, social, developmental, and economic factors as reasons which engendered endemic poverty, marginalization, and gross environmental degradation. Amaraegbu (2011) summed up this view by pointing out that the Niger Delta conflict has escalated into a multidimensional resistance with varied strategic undertones. This in turn triggers widespread social discontent, sense of powerlessness, relative deprivation, and frustration on the part of the residents of the region (Amaraegbu, 2011). Agbonifo (2009) and Amaraegbu (2011) alleged that the connection between environmental degradation perception of injustice, dispossession, infrastructure 


\section{Journal of Terrorism Research}

development issues, and political marginalization provides the context within which to understand the persistent conflicts in the region. Researchers on Niger Delta described the current state of the region in various forms. For example, Idowu (2012) described the region as the goose that lays the golden egg but the most environmentally fragile. Paki and Ebienfa (2011) referred to the region as one of the least developed parts of Nigeria. Nte et al. (2010) described it as one of the most insecure places in the world. According to Okpara (2012), the gas deposits and abundant oil, which should have been a blessing in the Niger Delta region, are now referred to as the oil curse. The gas flares produce constant brightness every day and night. Egbe (2012) maintained that the chemicals produced by the gas flares can cause heart problems, chest pain, breathing problems, bad odors, cancer, eye irritation, global climate change, induce asthma attack, increase death rate, and reduce ability to exercise.

Over the years, the Nigerian government has adopted several policies and implemented different developmental and poverty alleviation programs aimed at enhancing socioeconomic development, eradicating or alleviating poverty in the Niger Delta region (Amadi \& Abdullah, 2012; Oluduro \& Oluduro, 2012). While some of these government initiatives and development projects are laudable, they have however failed to achieve enduring peace in the region (Akpan et al, 2012; Oluduro \& Oluduro, 2012). In support of this view, Nwagboso (2012) emphasized that in spite of these intervention strategies, the insecurity and conflicts in the region persisted. It is against this background that the late Nigerian President Musa Yar'Adua granted presidential amnesty to the Niger Delta militants on conditions that they renounce violence and give up their weapons during a stipulated period in 2009. The introduction of the amnesty initiative witnessed a temporary reduction but did not completely put an end to the crime rate and violence that is characteristic of the Niger Delta region.

The unanswered cries and agitations of the indigenous people to control their own natural resources is a significant root cause of the Niger Delta crisis. Demands by the people of the Niger Delta region dates back to the 1990s when the Movement for the Survival of Ogoni People (MOSOP) in 1992 protested International Oil Companies (IOCs) operations and demanded justice from oil companies. MOSOP founded in 1990 had the mandate to campaign non-violently to promote democratic awareness, protect the environment, seek social, economic and physical development for the Niger Delta region, protect the cultural rights and practices of the Ogoni people, and seek appropriate rights of self-determination. On the contrary, the Niger Delta People Volunteer Force (NDPVF) is a militant youth organization created in late 2003 by Mujahid Dokubo-Asari. The group was involved in oil siphoning, attacking oil company infrastructure, demanded that international oil companies in the Niger Delta cease operating, and in September 2004, declared an "all-out war" against the Nigerian government. Asari Dokubo was arrested on charges of treason and was imprisoned at the federal security services headquarters in Abuja. Following his arrest in September 2006, the group fractured and some former NDPVF members formed the Movement for the Emancipation of the Niger Delta (MEND). On June 14, 2007, partially in an effort to pacify Ijaw demands, the newly installed government of President Umaru Yar'Adua released Asari from prison. MEND first came to public attention in January 2006. MEND has kidnapped oil company employees, bombed oil company infrastructure and military cars. MEND are a loosely organized secretive group who demand increased local control of oil resources and the eventual expulsion of international oil companies from the Niger Delta.

The above background provided the impetus to the Niger Delta youths who were confronted with the reality of abject poverty and lost livelihoods that threatens the existence and survival of the Delta communities and consequently generated feelings and perceptions of social, economic, political, and cultural alienation, humiliation, hostility, frustration, and deprivation. These were critical factors that facilitated in the birth of 


\section{Journal of Terrorism Research}

armed resistance and criminal activities in the Niger Delta. Nte, Eke, and Anele (2010) summed up the story of the Niger Delta and described it as a region that abounds with stories of conflicts based on invasions, nationalistic attacks, insurgency, and counter attacks for self-preservation.

\section{The findings of the study}

There is a difference between terrorism and other forms of political violence. While, this paper acknowledges that there are certain forms of violent resistance to perceived oppression, it also understands that demonstrating violent behavior might be illegal under certain national laws, and accepted under international humanitarian law. For instance, findings from Tobor (2014) suggest that the ex-militants do not identify themselves as terrorists but rather as freedom fighters who are engaged in a struggle to free their people from the perceived oppression of the government. When asked why he became a militant, P5 stated that 'I became a freedom fighter because of the need to do something to free my people from oppression." In answering the same question, P8 said, "I became a freedom fighter because I cannot stand by and watch my people suffer in silence." P3 expressed similar views stating, "Our people have oil and yet we do not have good roads, no hospital, no good water to drink and our people are suffering. This is why I became a freedom fighter." These responses confirm the assertion that the ex-militants do not consider themselves as terrorists but freedom fighters who are fighting for a just cause.

The issue of equity and justice in the distribution of oil revenue from the Niger Delta continues to drive the contextual discussion on the conflicts in the Niger Delta (Ojo, 2010). Understanding the politics of petro-economy and the intrigues that undergird revenue distribution and resource control is important in appreciating the development of the Niger Delta conflicts. Ako (2012) maintained that the underlying controversy over resource control was the conceptual ambiguity characterizing the Niger Delta conflict. Despite the violent and criminal features of the struggle, Akinola (2010) in his case for resource control stated that, what the Nigerian state construed as terrorism was nothing but the Niger Delta's clamor for their natural resources and resistance to perceived oppression. Tobor (2014) demonstrated that the exmilitants from Niger Delta were vociferous in their protest and rejected in totality marginalization, economic exploitation, social exclusion, bureaucratic corruption, lack of basic amenities, extreme forms of economic injustice, minimalism, and environmental pollution and degradation. For instance, P2 stated, "By nature we are a peaceful people, but we have been quiet for a long time and yet nothing has been done to develop our areas in spite of our oil." (p.145). Similarly, P14 said, "The Urhobos valuable belief systems include rights for their resources, social justice, and freedom from oppression." (p.145). P19 confirmed the similar thoughts as expressed by the above mentioned participants and stated that "The Urhobos believe in social justice, fairness, and their rights to their God given resources. They would do anything to fight for what rightfully belongs to them." (p. 146). According to P2, "Our farmlands and fishing ponds have been destroyed without any adequate compensation, we have cried out to the federal government for so long to no avail." (p.145). Tobor (2014) suggested that these concerns were the driving forces that fueled the crisis.

The literature reviewed is consistent with the findings. For instance, Inokoba and Imbua (2010) stated that the refusal of the Nigerian state to hearken to the yearnings, and aspirations of the Niger Delta people for equity in the distribution of oil and gas wealth to the area fueled the frustration, deep anger, desperation, restiveness, insurgency, militancy and conflicts in the Niger Delta. Deprivation theory is one competing theory of social movement that can be used to explain the phenomenon of militancy in the Niger Delta region of Nigeria. According to Anele and Omoro (2012), Marx, the foremost exponent of this theory, used it to explain how 


\section{Journal of Terrorism Research}

the working class under the capitalist system of production was exploited. The relative deprivation theory is when people feel that they deserve more than what they have got. This may lead to frustration, which in turn leads to aggression. It often occurs when expectations are rising but are not met. Nwagboso (2012) explained that when expectations exceed actual achievement regardless of the attainment of absolute levels of economic consumption, frustration sets in, which turns to anger and violence. According to Omotola (2010), the end result of this theory is that human beings will always resort to violence to either protest or challenge the existing structure of deprivation and struggle for compensation, reparations, or redress (p. 39).

A majority of the study participants mentioned the strong belief in their rights as human beings, freedom from oppression, social justice, equality, fairness, and rights to their God given natural resources (Tobor, 2014). For instance, P20 stated, "I joined a militant group because of my strong belief in social justice, equality, and fairness. We have Warri Refinery, Kokori Flow Station and other oil installations in our land and yet our people continue to suffer." (p.144). Similarly, P2 said, "As a human being we have to fight to protect our rights. We have to fight for what belongs to us. We have been peaceful and yet nothing was done about our suffering." (Tobor, 2014, p. 145). Some of the participants said they had been peaceful in the past and yet nothing was done to ameliorate their sufferings, or address their concerns, they therefore had to resort to whatever means necessary to draw attention to their just cause (Tobor, 2014).

All the study participants maintained that peace and stability can be restored if the federal government and multinational oil corporations embark on genuine rapid development of the region, by providing modern infrastructural facilities including tarred roads, pipe borne water, hospitals, institutional facilities, employment opportunities, and award scholarships to residents of the region (Tobor, 2014). For instance, one of the participant stated "It is important that the multinational corporations operating in the region to empower the people and compensate them for destruction to their farmlands and properties" (p.148). The literature reviewed is consistent with these assertions. For instance, Akpan and Ering (2010) recommended that addressing economic, environmental, social, and political concerns of the Niger Delta people is a likely solution to the persistent crises.

Tobor (2014) indicated that a majority of the study participants advocated that resource control should be absolute, while the federating states including the Niger Delta contribute a fraction of their income for federal upkeep. This assertion is consistent with the Ijaw Youth Council Kaiama declaration stance on resource control (Ako, 2012). Other proponents such as Arowolo (2011) who advocated for proportional access to the revenues accruing from the Niger Delta explained that such increases would afford indigenes of the region opportunities to enjoy access to the resources and benefits of their ancestral land. The purpose of resources agitation is to have reasonable percentage of the oil revenue allocated to the Niger Delta that produces over $80 \%$ of Nigeria's foreign exchange (Orokpo, 2012). The resultant argument for what portion or percentage of the revenue accrues to either the Nigerian state or the Niger Delta became the sensitive issue that drove the conflict. Tobor (2014) emphasized that the feeling of deprivation and marginalization in the distribution process left the indigenous inhabitants of the Niger Delta region aggrieved thus leading to clamor for expanded share of the income. According to Tobor, the responses from the participants also suggest that some of them became militants because of their strong belief in these views. These responses are also consistent with what was suggested in the literature reviewed. For instance, Freire (1997) emphasized that people who perceive the reality of oppression as a limiting situation will engage in a struggle to transform that situation. The response from the participants indicates that they felt oppressed because their source of livelihood had been destroyed without adequate compensation (Tobor, 2014). This was a significant reason why they joined militant groups. Failure on the part of the Nigerian state to increase the share of the Niger 


\section{Journal of Terrorism Research}

Delta states beyond 13\% in 50 years led to an exponential increase in crimes, such as kidnapping of oil workers, abduction, vandalism of oil installations, and arms struggle with the agents of the Nigerian state.

\section{Conclusion}

The purpose of this study is to find out whether the activities of the Niger Delta militants can be classified as acts of terrorism or a clamor for resource control. In answering this question, the study demonstrated that there is danger in adopting the sweeping appellation of terrorism on any individual or groups because it evokes demeaning emotions and incites ideological mindset that seems to alter the very fundamentals at stake in any contextual scenario. The definitional haze surrounding the definition of terrorism is not just limited to the international community, but also to the Nigerian situation with particular emphasis on the Niger Delta conflict. Understanding the background of the Niger Delta study helped the study to arrive at a logical conclusion on how to classify the activities of the Niger Delta militants. The struggle of the Niger Delta region for oil-based resource control started from the 1960s. The people of the region embarked on peaceful and violent struggle for the emancipation of the Niger Delta from the economic exploitation of the Nigeria state (Agwu, 2011). The initial struggle for developmental and environmental justice later changed into youth militancy with its attendant consequences (Tobor, 2016). The Nigerian state employed state violence in protecting its core national interest in the oil revenue derived from the Niger Delta (Uzodike \& Isike, 2011).

In all, proponents of terrorism school of thought relied heavily on the violent and criminal characteristics of the conflicts to buttress their position (Inokoba \& Imbua, 2010). While the perceptions of the study participants interviewed offered an opportunity to balance the argument of whether their activities as militants could be classified as terrorism or a clamor for resource control, the literature reviewed also provided the platform to draw a reasonable conclusion. While Onuoha (2008) focused on the violent crimes associated with the activities of the Niger Delta militants, the definitional haze that surrounds the concept and construction of terrorism lack strong literature references based on terrorism. On the other hand, Orogun (2010) added a new dimension to the criminal perspective of the Niger Delta conflict by drawing attention to the highly organized domestic oil bunkering and a well-coordinated international smuggling of illegal crude oil from the Niger Delta. While the criminal elements to the conflict could be adjudged localized, it sufficed to conclude that it qualified for transnational criminal cartel given the volume of international pirates and multinationals remotely and overtly involved. It is noteworthy to mention that interrelated factors created conditions for the conflict. The Niger Delta is a strange paradox as it represents one of the extreme conditions of poverty and lack of development in the country, despite its oil and gas resources. Tobor (2014) suggested that these factors motivated conflicts against the Nigerian government, accused of development neglect and deprivation, and against the oil companies for neglecting corporate social responsibility in the region. For instance, one of the participants interviewed stated, "Look at our farmlands, they have been destroyed by these oil companies and our people have not been adequately compensated. No light, no good roads, no good hospitals." (p. 145). While sharing similar thoughts on the same question, another participant said, "We have to fight for what belongs to us. We have been peaceful and yet nothing has been done about our suffering." (p.145). This is also consistent with the literature reviewed. For instance, Ojo (2010) enthused that oil wealth distribution should accommodate derivation, ecological impact, and other socio-economic indexes that provoke resentment and conflicts between the Nigerian state and the states of the Niger Delta. Failure to achieve these goals by successive Nigerian governments became 


\section{Journal of Terrorism Research}

the harbingers of the grievances, frustration and anger of the region, leading to conflicts (Orokpo, 2012).

If the definition of Bonager et al. (2007) of terrorism, that terrorist acts are forms of violence strategically used by aggressors to incite fear, terror or fright in civilian populations, is anything to go by then the classification of the Niger Delta conflict fails to pass for terrorism. This definition creates a classification ambiguity because of the Niger Delta militants' perceptions of the exploitative tendencies of both the federal government and multinational oil companies. The study participants (ex-militants) view the federal government as posing an obstacle to their natural petroleum resources. When asked whether they consider themselves as terrorists, all the study participants maintained that they were not terrorists but freedom fighters who were fighting for a just cause (Tobor, 2014). For instance, according to one of the ex-militants interviewed "I abhor violence. However, I cannot stand by and watch my people suffer in silence. Our people have oil and yet we do not have good roads, no hospital, no good water to drink and our people are suffering. This is why I became a freedom fighter. However, when the amnesty was introduced, it provided me an opportunity to change my way of life and also bring peace to our land.” (Tobor, 2014, p.159).

All the participants mentioned the strong belief in their rights, social justice, equality, fairness, and entitlements to their God given natural resources (Tobor, 2014). For instance, on the issue of rights, fairness, and justice, one of the study participants stated, "The Urhobos believe in social justice, fairness, and their rights to their God given resources. They would do anything to fight for what rightfully belongs to them." (p.146). These assertions from the study participants insulate the Niger Delta conflict from terrorism. The view that terrorists are rational, purposeful and directional in their goals and objectives draws another definition attention. This definitional haze brings the Niger Delta resource control struggle to rational constructivism analysis. The demand for increased allocation of income accruing from oil and gas explored from their lands and waters negate the classification of the militants as terrorists. This is because the Nigerian state neglects the region which led to insurrection in the first place and thus the study does not classify a clamor for natural resources as an act of terrorism. The social implications of this study are that the research findings derived from the study may contribute towards formulating policies that will address the root causes of the Niger Delta crisis and help alleviate the current sufferings that are being experienced by the indigenous inhabitants of the region.

\section{About the author: John Oghenero Tobor has a PhD degree in Public Policy and Administration with Specialization in Terrorism Mediation and Peace. He is an educator/researcher/activist/security consultant who focuses on social change initiatives. He is the founder and chief executive officer of worldwide security consultants Ltd and Move Nigeria Forward Initiative - a nongovernmental and non-profit organization based in Nigeria and in the United States of America. He is a member of the Institute for Association for Counterterrorism \& Security Professionals, American Society for Public Administration, American Society for Industrial Security, and Foreign Policy Association of Harrisburg. He has written and published several scholarly articles. He resides in York, Pennsylvania State, United State of America and can be reached on tobor_nero@ yahoo.com.}

\section{References}

Agbonifo, J. (2009). Oil, insecurity, and subversive patriots in the Niger Delta: The Ogoni as agent of revolutionary change. Journal of Third World Studies, 26(2).71-107. 


\section{Journal of Terrorism Research}

Agwu, F. A. (2011). From rebellion, insurgency to belligerency: the Niger Delta oil war in international law. Ibadan: University Press, Plc.

Akinola, S. R. (2010). Restructuring the public sphere for social order in the Niger Delta through polycentric planning: What lessons for Africa? African \& Asian Studies, 9(1/2), 55-82.

Ako, R. T. (2012). Re-defining corporate social responsibility (CSR) in Nigeria's post- amnesty oil industry. African Journal of Economic and Management Studies,3(1). 9-22. doi:10.1108/20400701211197258

Akpan, F., \& Ering, S.O. (2010). The politics of amnesty and oil-related conflict in the Niger-Delta region of Nigeria. European Journal of Social Science, 17(2), 146-153.

Amadi, B. O., \& Abdullah, H. (2012). Poverty alleviation through corporate social responsibility in Niger Delta, Nigeria. Asian Social Science, 8(4), 57-67. doi:10.5539/ass.v8n4p57

Amaraegbu, D. (2011). Violence, terrorism and security threat in Nigeria's Niger Delta: An old problem taking a new dimension. African Journal of Political Science and International relations, 5(4), 208-271.

Anele, K. A., \& Omoro, J. (2012). Mobilizing the militants in the Niger Delta for national development: Prospects and Challenges. Journal of International Diversity, 2012(1), 107-122.

Arowolo, D. (2011). Nigeria's federalism and the agitation for resource control in the Niger-Delta Region. OIDA International Journal of Sustainable Development, 2(7), 3-88.

Badmus, I. A. (2010). Oiling the guns and gunning for oil: Oil violence, arms proliferation and the destruction of Nigeria's Niger Delta. Journal of Alternative Perspectives in the Social Sciences, 2(1), 323-363.

Bassey, C. O. (2012). Oil and conflict in the Niger Delta: A reflection on the politics of state responses to armed militancy in Nigeria. Mediterranean Journal of Social Sciences, 3(11), 77-90. doi:10.5901/mjss.2012. v3n11p77

Benet, W. J. (2006). The polarity management model of workplace democracy. Doctoral dissertation, Ontario Institute for Studies in Education of the University of Toronto, Canada. Dissertation Abstracts International-A 67/06, Dec 2006, Publication No. AAT NR15724.

Benet, W. J. (2012). Managing the polarities of democracy: A social economy framework for healthy, sustainable, and just communities. Paper presented at the Association for Social Economics' 14th World Congress of Social Economics, Glasgow, Scotland.

Benet, W. J. (2013). Managing the polarities of democracy: A theoretical framework for positive social change. Journal of Social Change, 5(1), 26-39. doi:10.5590/JOSC.2013.05.1.03

Bongar, B., Brown, L. M., Beutler, L. E., Breckenridge, J. N., \& Zimbardo, P. G., (2007). Psychology of terrorism. New York, NY: Oxford University Press.

Chase, E. (2013). Defining terrorism: A strategic imperative. Small War Journals. Retrieved from: http:// smallwarsjournal.com/jrnl/art/defining-terrorism-a-strategic-imperative

Cooper, H.H. (2001). Terrorism: The problem of definition revisited. American Behavioral Scientist, 44(6), 881-893. Retrieved from http://proquest.umi.com.ezp.waldenulibrary.org/ pqdweb? did=66946156\&sid=1\&Fmt=6\&clientId=70192\&RQT=309\&VName=PQD\&cfc=1

Egbe, O. D. (2012). Oil transnational corporations (TNCs) and dislocations in oil fence- line communities in the Niger Delta, Nigeria. Journal of Alternative Perspectives in the Social Sciences, 5(1), 154-178.

Ekeh, P. (2008). On the matter of clans and kingdom in Urhobo history and culture. Urhobo Historical Society. 


\section{Journal of Terrorism Research}

Ekpeyong, O., \& Dienye, E. H. (2010). Political identity and the Niger Delta crises. Culture \& Religion Review Journal, 2010(4), 1-10.

Etemike, L. (2012). International dimension of the Niger Delta crisis: An insight into Nigeria's foreign policy challenges. Journal of Alternative Perspectives in the Social Sciences, 4(3), 577-593.

Freire, P. (1970/1997). Pedagogy of the oppressed. New York, NY: The Continuum Publishing Company. Idowu, O. F. (2012). Niger Delta crises: Implication for society and organizational effectiveness. British Journal of Arts and Social Sciences, 7(11).

Ifedi, J. P., \& Anyu, J. N. (2011). “Blood Oil,” ethnicity, and conflict in the Niger Delta region of Nigeria. Mediterranean Quarterly, 22(1), 74-92. doi: 10.1215/10474552-1189665

Inokoba, P. K., \& Imbua, D. I. (2010). Vexation and militancy in the Niger Delta: The way forward. Journal of Human Ecology, 29(2), 101-120.

Nacos, L.B. (2010). Terrorism and counterterrorism (3rd ed.). New York, NY: Pearson Education Inc

Nacos, B. L. (2012). Terrorism and counterterrorism, 4th Edition. Longman-Pearson.

Nte, N. D., Eke, P., \& Anele, K. (2010). Rural intelligence gathering and the challenges of counter insurgency: Views from the Niger Delta. Bangladesh e-Journal of Sociology, 7(1), 21-32.

Nwagboso, C. I. (2012). Security challenges and economy of the Nigerian State (2007 - 2011). American International Journal of Contemporary Research, 2(6), 244-258

Oakley, P. (1989). Community involvement in health development. An examination of the critical issues. Geneva, WHO.

Obi, C. I. (2010). Oil extraction, dispossession, resistance, and conflict in Nigeria's oil- rich Niger Delta. Canadian Journal of Development Studies, 30(1-2), 219-236.

Odoemene, A. (2011). Social consequences of environmental change in the Niger Delta of Nigeria. Journal of Sustainable Development, 4(2), 123-135. doi:10.5539/jsd.v4n2p123

Ogbodo, S. M. (2010). Environmental issues and Nigeria's Niger Delta crisis. Implications for sustainable development and global peace. OIDA International Journal of Sustainable Development, 02(03). 17-21.

Ogege, S. O. (2011). Amnesty initiative and the Dilemma of sustainable development in the Niger Delta region of Nigeria. Journal of Sustainable Development, 4(4), 249-258. doi: 10.5539/jsd.v4n4p249

Ojo, E. O, 2010). The politics of revenue allocation and resource control in Nigeria: implications for federal stability. Federal Governance, 7(1), 15-38. Retrieved from http://library.queensu.ca/ojs/index.php/fedgov/ article/view/4387/4405

Okpara, C. I. (2012). Right to a clean and healthy environment: The panacea to the Niger Delta struggle. Journal of Politics and Law, 3-9. doi:10.5539/jpl.v5n1p3

Okpo, O. C., \& Eze, R. C (2012). Vandalization of oil pipelines in the Niger Delta region of Nigeria and poverty: An overview. Studies in Sociology of Science, 3(2), 13-21. doi:10.3968/j.sss.1923018420120302.2950

Olankunle, M. F. (2010). Women's response to the question of development in the Niger Delta, Nigeria. Journal of Comparative Research in Anthropology and Sociology,1(1), 133-149.

Oluduro, O., \& Oluduro, O. F. (2012). Nigeria: In search of sustainable peace in the Niger Delta through the amnesty programme. Journal of Sustainable Development, 5(7). 48-61. doi: 10.5539/jsd.v5n7p48 
Oluwaniyi, O. O. (2011). Post-amnesty programme in the Niger Delta: Challenges and prospects. Conflict Trends, 4, 46-54.

Omotola, J. S. (2010). "Liberation movements" and rising violence in the Niger Delta: The new contentious site of oil and environmental politics. Studies in Conflict \& Terrorism, 33, 36-54. doi:10.1080/10576100903400597

Onuoha, F. C. (2008). Oil pipeline sabotage in Nigeria: Dimensions, actors and implications for national security. African Security Review, 17(3), 99-115. doi:10.1080/10246029.2008.9627487

Orogun, P.S. (2010). Resource control, revenue allocation and petroleum politics in Nigeria: the Niger Delta question. GeoJournal, 75(5), 459-507. Retrieved from http://link.springer.com/ article/10.1007\%2Fs10708-009-9320-7

Orokpo, O. (2012). Revenue allocation commissions and contradictions in Nigeria's federal system: A revisitation. Journal of Science and Policy Review. Retrieved from http://www.academia.edu/2614756/ revenue_allocation_commissions_and_the contradictions_inNigerias_federal_system:a_revisitation Paki, F. A., \& Ebienfa, K. I. (2011). Militant oil agitations in Nigeria's Niger Delta and the economy. International Journal of Humanities and Social Science, 1(5).

Rubenstein, R. E. (1988). Alchemists of revolution: Terrorism in the modern world.

Tobor, J. O. (2014). Urhobo culture and the amnesty program in Niger Delta, Nigeria: An ethnographic case study. Doctoral dissertation, Walden University, Minneapolis, Minnesota, U.S.A. ProQuest, UMI Dissertations Publishing, 3645926.

Tobor, J. (2016). Culture and the amnesty program in the Niger Delta region of Nigeria. European Journal of Research in Social Sciences, 4(3), 14-22.

Uzodike, U. O., \& Isike, C. (2009). Whose security? Understanding the Niger Delta crisis as a clash of two security conceptions. Institute for Security Studies, 18(3), 103-116. 